\title{
A Comparative Study of the Turkish and German Health Care Systems with regard to Quality Management in Psychiatric Hospitals
}

\author{
"Fatma Kantaş Yılmaz ${ }^{1}$ \\ Tarık Uğur ${ }^{2}$ \\ Michael Rese $^{3}$ \\ 'Facullty of Ilealth Sciences, Iniversity of Ileallh Sciences, Istanbul, Tlurkey

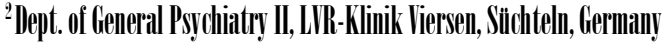



\begin{abstract}
This paper investigated the delivery of health services based on data recorded at two medium-sized hospitals: Erenköy Mental Health Research and Training Hospital located in Istanbul/Turkey and LVR-Klinik Viersen in Germany. A comparison of quality management systems in terms of certification and accreditation procedures, satisfaction of patients and health care professionals as well as quality indicators revealed structural similarities and differences in health care practices. Both quality management systems have been undergoing radical changes. Social health insurance system was established in Germany in $1880 \mathrm{~s}$ and the primary intention was to incorporate the entire society in the scope of health care services. In the framework of the Health Transformation Project in Turkey, tremendous changes have been made since 2003 and a General Health Insurance System, which is similar to the health care system in Germany, was set up. Differences are observed in the delivery of health care services in both countries, in which health care expenditures have increased in recent years. In this paper, health care systems in Germany and Turkey are examined based on on-site examinations, which were conducted in December 2016 February 2017 in LVR-Klinik Viersen, Germany. Quality studies performed in the hospitals in Germany and Turkey were comparatively discussed. Similar to a high number of other countries, quality practice gained importance along with reform studies that were performed in health care systems in Germany and Turkey. Several studies on the hospital quality of both countries pointed out to some practical differences, although similarities were also found.

Keywords: Health care system, Germany, Turkey, hospital quality management, health insurance system

JEL:I10, I11, I12, I18, I19
\end{abstract}

Federal Republic of Germany is the most populous country in the European Union with its population of 80.6 million in 2017. In 2015, the Gross Domestic Product (GDP) in Germany was USD 3363.45 and the GDP value of Germany accounts for the 5.42 percent of the global economy (Tradingeconomics.com, 2017). Germany comprises of 16 provinces and its capital (Berlin) is the largest city. In 2014, the life expectancy at birth was 81.2 (see Figure 1). It was 79 years for men and 84 years for women (OECD/EU, 2016). Although, the gap between the West and the East in life 
expectancy at birth widened in the 1990s (3.5 years for men, 2.8 years for women), it has been gradually decreasing (In 2010, 1.30 years for men and 0.30 years for women) (Busse and Blümel, 2014).

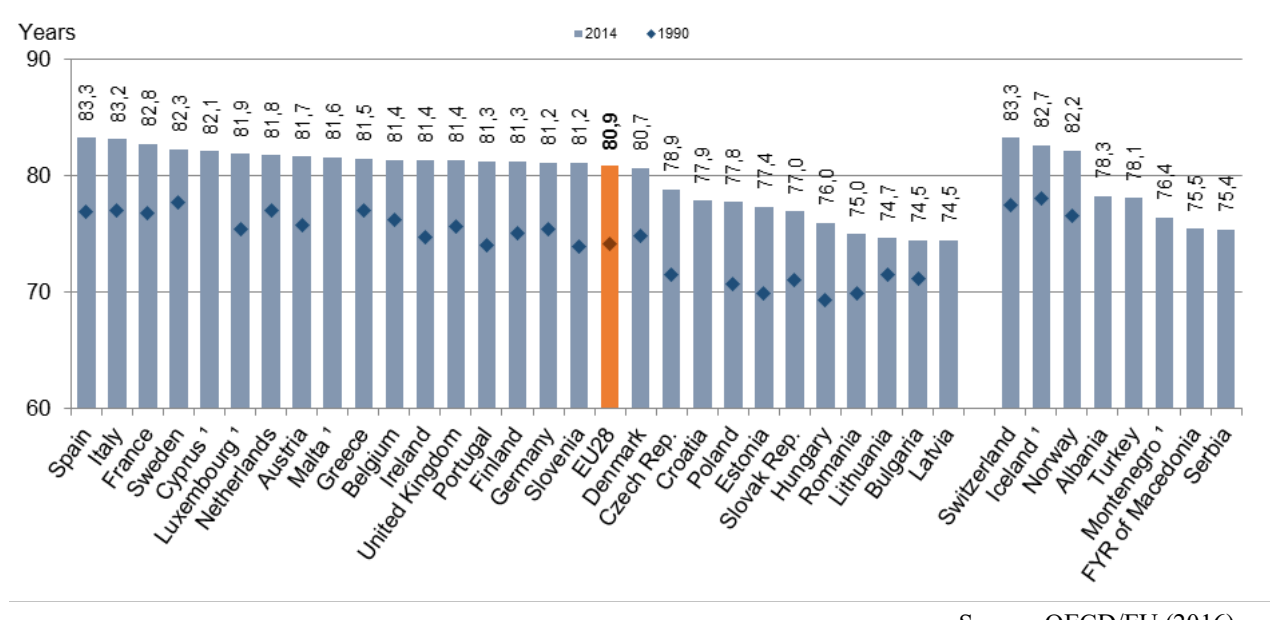

Source: OECD/EU (2016)

Figure 1. Life Expectancy at Birth, 1990 and 2014

Turkey's population reached 78.7 million in 2015 (Worldometers.info, 2017). The gross domestic product (GDP) in Turkey was USD 711.88 billion and the GDP value accounts for 1.16 percent of the global economy (Tradingeconomics.com, 2017). Life expectancy at birth was 78.10 years in 2014: 80.90 years for women and 75.4 years for men according to the 2016 data from OECD (the Organisation for Economic Coᄀoperation and Development) (OECD/EU, 2016). The 2015 statistics from the Ministry of Health report that the life expectancy at birth was 78 years (80.70 years for women and 75.30 years for men) (the Ministry of Health, 2015). According to the data from the OECD, the life expectancy at birth in Germany was above the OECD average and it was found in Turkey to be close to the OECD average (OECD/EU, 2016). Turkey and Germany share the common ground that the health care services are delivered mainly in public and non-profit hospitals (in non-profit hospitals in Germany, in particular). Health care services are frequently funded by compulsory health insurances. Health care expenditures in both countries have gradually increased and the share of private sector in the delivery of health care services has been gradually increasing in Turkey and Germany.

This paper will give an overall look at health care systems in both countries and quality studies performed in Germany and Turkey will be comparatively evaluated. This study was carried out on behalf of the Turkish Ministry of Health during on-site investigations in LVR-Klinik Viersen in Germany as part of the "Regulation on Overseas Training for Civil Servants" and under the title of "Quality 


\section{Yılmaz et al.}

Management and Technology Assessment in Health Care". Studies were conducted in the Quality Department of LVR-Klinik Viersen that provides service in the field of psychiatry within LVR Klinik Group. This research was carried out on-site. Psychiatric services constitute a special field in the delivery of health care services. They vary in a high number of aspects, depending primarily on the physical structure of the place of the service, human resources, patient and employee safety and quality standards. In this context, psychiatric services are discussed as a separate chapter within the quality standards of the Ministry of Health in Turkey just like in many other countries. Psychiatryspecific quality standards and indicators were developed. This study presents an overview of health care systems and quality studies in both countries and can provide information for health care professionals and researchers in this field. Moreover, it provides a reference for future studies.

\section{LITERATURE REVIEW}

\section{Healthcare Systems in Germany and Turkey}

The mechanism of decision-making in health care system of Germany is shared at federal and provincial level (Busse and Blümel, 2014). A structure, extending from national to local level, is cited in the practices of health care system (Ataç and Sur, 2016). At the administrative level, the parliament and the Federal Ministry of Health are responsible for legislative and supervision functions. Financing mechanisms of services and the health care system as a whole are regulated within the framework of federal rules. Policy making for health care services is shared between the federal government, the federal states and several self-governing bodies such as sickness funds and physicians' associations. The state-level responsibility lies in the financing of the hospital infrastructure, disease prevention, environmental hygiene, and vaccination. However, these tasks were largely transferred to local governments (municipalities) (Renger and Czirfusz, 2016).

The Federal Joint Committee (G-BA) is a self-governing, common and the highest decisionmaking body of dentists, physicians, hospitals, and health insurance funds in Germany (Gemeinsamer Bundesausschuss, 2017). It was commissioned in 2004 to determine the requirements of quality assurance within the context of health reform. It gives instructions for the beneficial catalogue of compulsory health insurance for more than 70 million insured individuals. Therefore, it determines which health care services will be funded by compulsory health insurance. The Federal Joint Committee also determines measures for quality assurance in the areas of inpatient and outpatient services in health care system (Gemeinsamer Bundesausschuss, 2017).

In Turkey, the Ministry of Health serves as the single service provider in preventive services and the major provider in primary care and hospital services. The Ministry of Health consists of the Central 
International Journal of Management, Economics and Social Sciences

Organization, Provincial Organization, and associated institutions (Karar, 2013). With the passing of the Health Transformation Program in 2003 (Legislative Decree No. 663 published in November 2011) the central organization of the Ministry of Health that assumes planning and supervisory roles was restructured. Public Hospital Associations (PHAs) were established and the "health administration" model was extended to secondary and tertiary care institutions. Thus, tremendous changes were made in the delivery of health care services.

\section{Financing for Health}

It is essential to refer to three basic models of health care system for examining financing methods for health care services. In the broadest sense, three models are applied for financing resources: the Bismarck model that is financed by Social Health Insurance and services are offered mainly by the public; the Beveridge Model that is a National Health Care Service covering funding with taxes and private health insurance. Third model is private insurance. However, the latter may differ considerably (Tatar, 2014; Wild and Gibis, 2013)

Social insurance in Germany was first initiated legally by Otto von Bismarck in 1883 (Istanbulluoglu et al., 2010). The social security system is currently financed from national insurance contributions paid by employers and employees as well as general tax revenues. Employees are obliged to pay contributions to sickness insurance, long-term health care insurance, unemployment insurance and pension insurance. The level of employees' contribution to a statutory insurance coverage is a fixed percentage of their earnings (European Commission, 2017). Unemployment insurance is mandatory for all employees and is implemented by the Federal Employment Agency. Unemployment benefits are paid if you are unemployed and have worked (and paid contributions) for at least 12 months in the last two years (Just Landed, 2017).

Health insurance has been made compulsory for almost all citizens (except of people with high income and public officers) and permanent residents in Germany since 2009. In 2016, a total of 71.45 million people (71.12 million in 2015) which was nearly 88 percent of the population were covered by compulsory health care insurance, and registered at one of 124 sickness funds (January 2015) (GKV-Spitzenverband, 2017). Since the adoption of the Health Insurance Law in 1883, Compulsory Health Insurance (Gesetzliche Krankenversicherung-GKV) has constituted the necessary organizational structure for the introduction of health care services to the public and established the system with sickness funds, institutions and authorized doctors (Günaydin, 2016). In compulsory health insurance, payable premiums are shared between employees and employers at specific ratios. Contribution to be paid is directly deducted from salaries of employees, and unemployed spouse and children of the insured employee may benefit from free compulsory insurance services under insurance 


\section{Yılmaz et al.}

coverage. For anyone who enjoys compulsory health insurance, the new ratio was determined upon the enactment of health fund as equal contribution as of July 2009 (Hoffmann and Schulze, 2014; Yaman, 2014). As of January 1, 2011, this ratio was determined as 15.5 percent of any gross income and it was stipulated that an employer would pay 7.3 percent and an employee would pay 8.2 percent (Yaman, 2014).

Compulsory health insurance system in Germany faces problems due to demographic changes such as increase in health care expenditures with increasing age, inadequacy of pension contributions to meet costs since premiums are proportional with incomes and the necessity of subsidization of the retired by employees. In 1990, four employees could meet costs of one retired individual but it is estimated that 3 employees are required to meet such costs in 2010 and two employees will be needed in 2030. German private health insurance sector implements three important precautions, including senility reserve, interest incomes and an additional premium fee of 10 percent in order to protect older insured individuals from unexpectedly high increases in the premiums (Yaman, 2014).

In Germany, high-earning individuals, public officers and self-employed people may be included within the scope of Private Health Insurance (PHI) (Renger and Czirfusz, 2016). People who are insured privately usually cannot return to compulsory health insurance system. In 2015, an annual income above 49.500 Euros (63.360 dollars) was required to switch into a private health insurance (in 2014, it was more than 4.050 Euros/month or 48.600 Euros/year) (Busse and Blümel, 2014). In 2014, 8.8 million people (11\% of the population) were covered by a private insurance (Mossialos et al., 2016). Occupations such as soldiers and police officers are generally included in the category of private occupational insurance (Renger and Czirfusz, 2016).

Private health insurance in Germany already includes a senility reserve. This aims to meet high health care expenditures that will occur during people's lifetime and especially during older ages. Back in the day, when privately insured individuals wanted to change their insurance company, their previous reserves used to remain in the former company. However, this drawback was eliminated by the Act to Strengthen Competition in the Compulsory Health Insurance on January 1, 2009 (Yaman, 2014), which allows transfer of senility reserves.

Another aspect of the German health care system is medical rehabilitation services that are introduced in the scope of Pension Insurances. Pension Insurance is an important pillar of the German social insurance system. Its primary goal is to ensure professional rehabilitation based on insurance liability before early retirement might be unavoidable. Therefore, early retirement due to health problems (invalidity pension) fills the gap if no sufficient recovery occurs and the working ability is partially or completely lost. An individual with chronic disease may also benefit from medical rehabilitation service, which is applied for full day outpatient services or overnight (Gutenbrunner et al., 
2015).

The health care system in Turkey is not included in one of three basic health care systems explained above, and amounts to a combined health care system. A general health insurance, which is based on the Bismarck Model, and a public assistance model as in the Beveridge system is applied. Health care services for Turkish citizens are mainly provided by public institutions, and they may also benefit from profit-driven private health care institutions that operate on a free market economy basis. Therefore, health care services vary by the supply and demand aspect (Yurdadog, 2013).

In 2003, three social security institutions (Pension Fund, Bag-Kur, and SSK) were gathered under the umbrella of the Social Security Institution (SGK) in Turkey and thus, the General Health Insurance (GSS) emerged. A financing system with contributions that are proportional to individuals' incomes was established. Insurance charges are pooled in a fund, which is subsidized from the state budget in case of deficits. In short, the GSS was set up to finance health care services that cover all citizens and is a social insurance system based on the collection of premiums from individuals who will benefit from this service (Çiftçi, 2014). Financing of health care services with taxes in Turkey generally functions with the rationale of "health care aid". The government meets treatment costs of lowincome individuals by "Yesil Kart (Green Card)" health insurance scheme.

\section{Healthcare Expenditures}

In Germany, according to the OECD Health Statistics money paid for health per capita was 4003 Euros (2015) and the percentage of health care expenditures within GDP was 11.1 percent in 2015 (Figure 2). Compulsory health insurance expenditures constitute 9.4 percent and private health care expenditures constitute 1.7 percent. Germany is the country with the highest health care expenditures among other European countries (OECD, 2016). Turkey lies at the list with its ratio of 5.2 percent. Most of the health care expenditures in Turkey are compulsory health insurance expenditures (4\%) like in Germany and private health care expenditures constitutes 1.2 percent (OECD, 2016).

When health care expenditures of Turkey and Germany were examined based on the type of financing in 2014 (Figure 3), it stands out that financing sources of both countries are comparable. In both countries, compulsory health insurance constitutes a major part of existing health care expenditures ( $78 \%$ and $56 \%$, respectively). Out-of-pocket expenses have a ratio of 18 percent in Turkey and 13 percent in Germany; it is more in Turkey. In Germany, 29 percent of health care expenditures were for inpatient medical service, 14 percent for long-term care service, 20 percent for medical materials, and 8 percent for collective services (OECD Health Statistics, 2016) (OECD, 2016).

\section{Delivery of Healthcare Service}




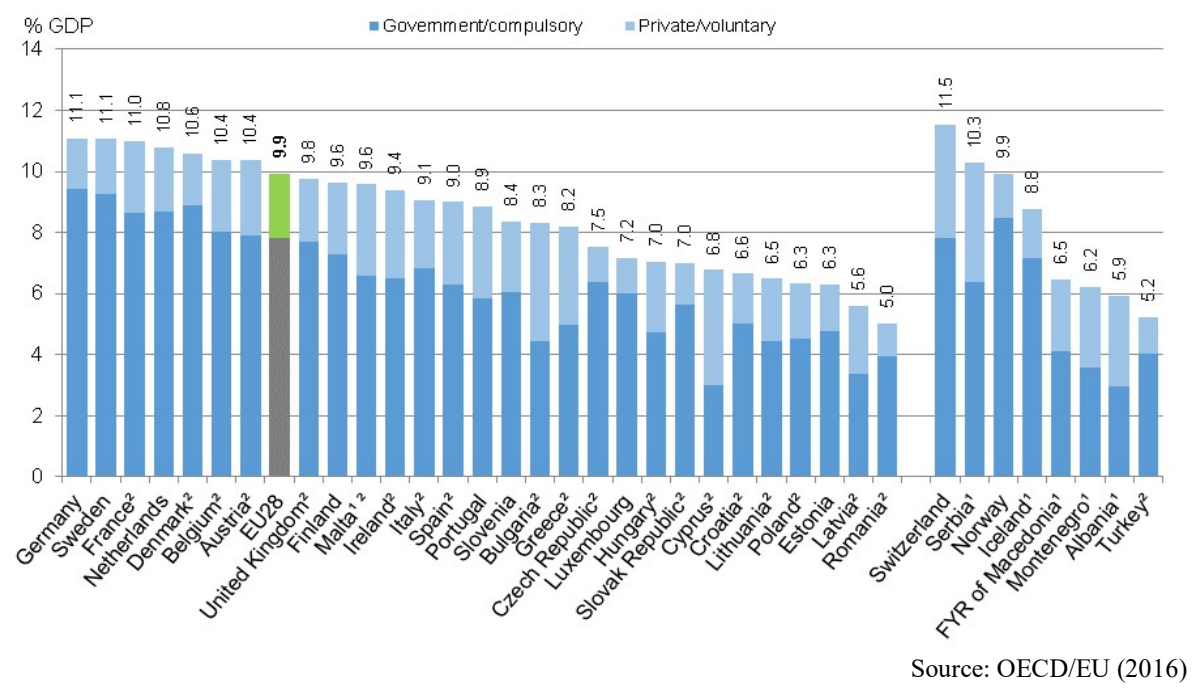

Figure 2. Healthcare Expenditures as a Share of GDP (2015 or nearest year)

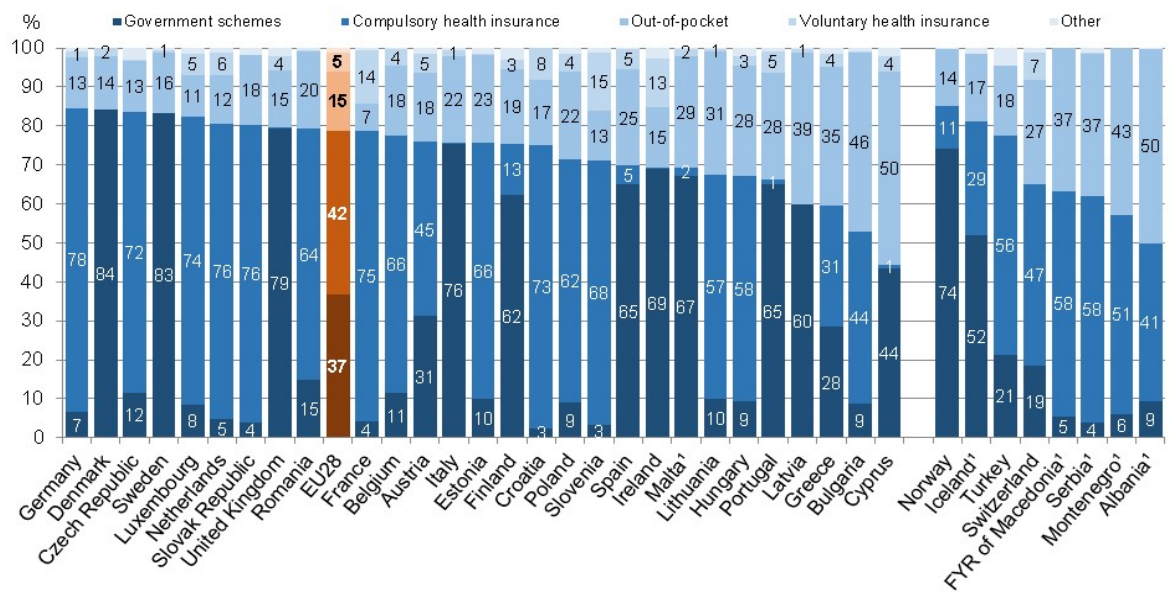

Source: OECD/EU (2016)

Figure 3. Current Healthcare Expenditures by Type of Financing (2014)

The most important feature of the delivery of health care service in Germany is the clear institutional separation between public health, ambulatory care and hospital care (Busse and Blümel, 2014). The number of hospitals was 2017 in 2012; and a total of 501.47 patient beds were present. The number of beds per 10.000 patients was 82.3 (Figure 4) and has the highest ratio among European Union countries. 48 percent of these beds were present in public hospitals, 34 percent were in the hospitals of non-profit organizations and 18 percent were in the private hospitals (OECD Health Statistics, 
2016). Although the number of beds for acute patients decreased since 1991, they still have a 60 percent higher ratio than other European Union countries (15 countries). While the mean duration of hospitalization was 12.8 days in 1991, it decreased down to 7.7 days in 2011 (Busse and Blümel, 2014). According to 2014 data, the European Union (EU28) average was 8 days, compared to an average of 9 days in Germany (OECD Health Statistics, 2016).

The delivery of health care services in Turkey is primarily based on treatment services and it is mostly provided by public hospitals matching a total of 1533 hospitals in 2015 . Out of these, 865 were affiliated to the Ministry of Health, 562 were in private ownership, 70 were university hospitals, and 36 were "other" hospitals. 122.331 of 209.648 hospital beds were the beds in the hospitals affiliated to the Ministry of Health (The Ministry of Health, 2015). The number of beds per 10.000 people was 26.6. The mean duration of hospitalization was with 4 days in Turkey in 2014; shorter than the OECD (8 days) and German (9 days) averages (OECD Health Statistics, 2016).

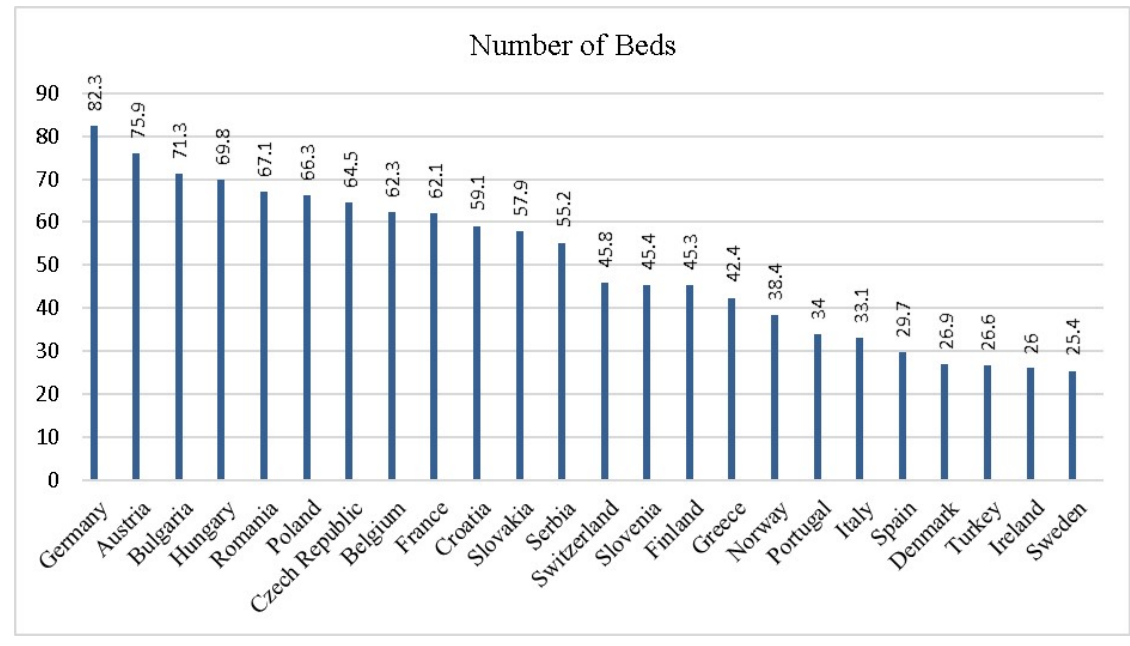

Source: OECD/EU (2016)

Figure 4. International Comparison of the Number of Beds per 10.000 People (2014)

In Germany, outpatient services are provided by profit service providers (except of the outpatients who get their therapy in an outpatient unit of a hospital). Patients have the right to choose their physicians, psychiatrists, dentists, and pharmacy. In 2012, 121.198 doctors have provided service within the scope of compulsory health insurance in Germany. 46 percent of these were working as family doctors whereas 54 percent were working as specialists. German hospitals have focused on inpatient care, and are strictly separated from outpatient services (Bussse and Blümel, 2014). However, the implementation of disease management programs has made the strict separation a little 


\section{Yılmaz et al.}

permeable. Public health services (for instance; control of infectious diseases, health promotion and education) are responsibilities of the state (Länder) (Busse and Blümel, 2014).

Germany has achieved a great improvement in palliative care centers, first of which was established in 1983 (Bag, 2012). Between 1996 and 2011, the number of palliative care centers increased from 28 to 231; and the number of bed hospices increased from 30 up to 179. In 2009, the number of palliative beds per million inhabitants was 17 and the total number of bed hospices was 18 . The total need is estimated as 25-30 beds per one million inhabitants (Busse and Blümel, 2014).

Preventive and basic health care services are provided within the scope of "Family Medicine Practices" in Turkey. Former Health Centers had been replaced by the "Family Medicine" system that is another component of The Health Transformation Program. The city of Duzce was chosen as pilot within the framework of the "Law on the Family Medicine Pilot Practice" (decree no. 5258 in 2004), more and more cities have been included ever since until the system covered the whole country in 2010. "Preventive health care services" that are provided by primary health care institutions were divided into two as "collective" and "individual" services. While collective preventive medicine services were allocated to "Community Health Centers" which in this respect have replaced the former Health Centers, personal preventive and therapeutic health care services have been left to the responsibility of family doctors (Erol and Özdemir, 2014). "Therapeutic health care services" which are the service types provided for diagnosis and inpatient treatment are provided by public hospitals affiliated with the Ministry of Health in Turkey or by private hospitals and medical faculties.

\section{Human Power in Healthcare}

In Germany, 4.9 million people work in health care sector which constitutes 11.2 percent of the total working population by the end of 2011 (Busse and Blümel, 2014). While the number of physicians per 1000 individuals was 4.1 in 2014, it was 1.8 in Turkey (Figure 5). The number of nurses per 1000 inhabitants was 13.1 in Germany whereas it is 1.9 in Turkey. The European Union average (EU28) is in between with 8.4. While the number of medical examinations per person was 7.1 for European Union average (EU25), it was 9.9 for Germany and 8.3 for Turkey in 2014 (OECD/EU, 2016). This situation shows that access to health care is more than the European Union average indication in both countries. According to Ministry of Health Statistics, the number of medical examinations per person was 8.4 in 2015 (The Ministry of Health, 2015).

\section{Quality Studies in Healthcare Institutions in Germany and Turkey}

Quality studies in European hospitals have led to standardized quality management programs, which ought to improve the clinical quality, to increase patient satisfaction and to decrease costs in the 


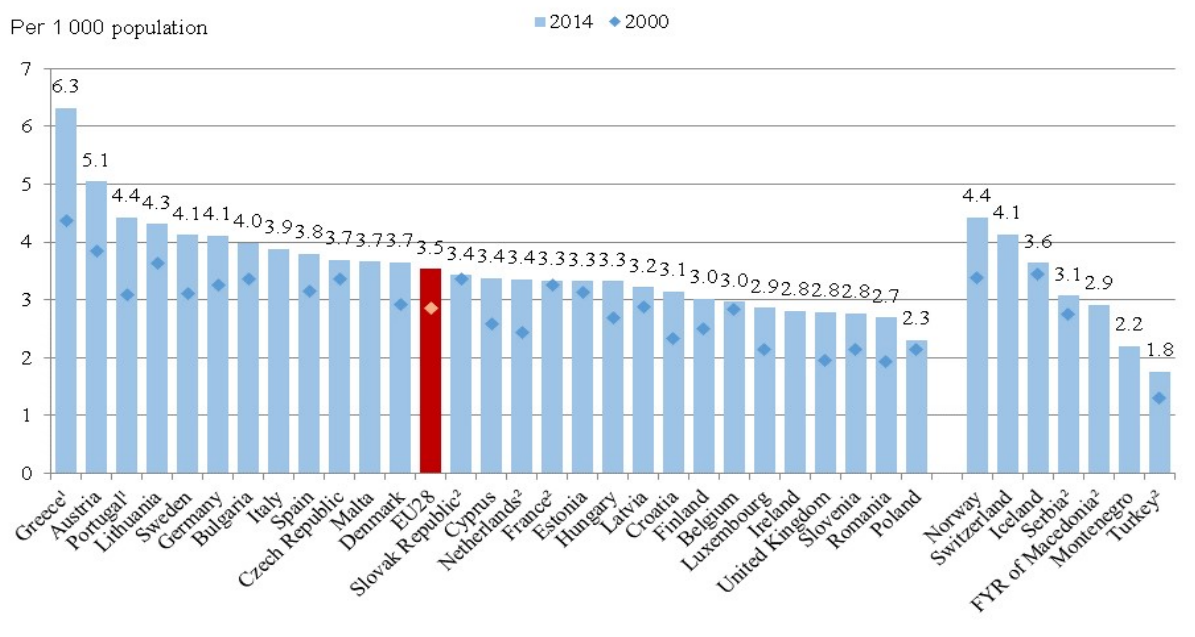

Source: OECD/EU (2016)

Figure 5. Practicing physicians per 1000 population in 2000 and 2014 (or nearest year)

scope of health promoting hospital strategies of the World Health Organization. In this context, quality management was required for all health care service providers in Germany in the scope of a health reform process in the 2000s. Hospitals had to implement an internal quality management system and continuously improve. Quality management aims to increase the treatment quality of the patients as well as the satisfaction of working staff. Since the 2000s until today the KTQ model, the DIN ISO 9001 or the EFQM model have been implemented in most German hospitals and were periodically certified (Halank, 2010). Since 2003 hospitals have been legally liable to publish quality reports regularly as a part of quality assurance. These reports provide information for the doctors who provide care after hospital treatment and for health insurance funds besides giving information to the patients and insured. Thus, the quality report gives information during treatment in a hospital and provides transparency for the stakeholders of the hospitals. The Federal Joint Committee (G-BA) gives decisions regarding quality, content and data format of the reports (Gemeinsamer Bundesausschuss, 2017).

Ongoing quality studies in the health care system in Turkey are mostly conducted by the government based on "quality and accreditation for qualified and effective health care service" that is the sixth component of Health Transformation Program (Küçükali and Ta ̧̧demir, 2016). The process, which has started with the TS-EN ISO 9001 certification program in the 1990s, continues with the establishment of National Accreditation System.

-Certification and Accreditation 
Yılmaz et al.

Quality certification in the most health care institutions in Germany is carried out by an independent organization called KTQ (The Cooperation for Transparency and Quality in Health care). Hospitals, clinics, health care centers (medical care center mvz), rehabilitation clinics, nursing homes, and hospices that have KTQ certification focus on patient satisfaction from hospitalization to discharge. KTQ is implemented in Germany on a voluntary basis (Domittner et al., 2013). Institutions make a payment for the KTQ certification process. Besides the ISO 9001 certification program is applied in some hospitals, rehabilitation clinics, nursing homes and in some specialized units (such as laboratory and pharmacy).

During KTQ certification process in Germany, processes are optimized within patient care system; and evaluation is made in six categories during certification (Domittner et al., 2013; KTQ, 2017).

$\checkmark$ Patient orientation

$\checkmark$ Staff orientation

$\checkmark$ Safety

$\checkmark$ Communication and information

$\checkmark$ Leadership

$\checkmark$ Quality Management

KTQ certification process includes 3 steps. These are self-assessment, external evaluation and a quality report and provision of certification (KTQ, 2017).

Self-assessment: The institution assesses itself based on KTQ catalogue that includes the questions of six categories. The self-assessment should uncover needs of improvement. Hospitals scrutinize their own quality management during this process. In the checklist, patient and staff orientation, hospital management and interdepartmental quality management are to be evaluated (KTQ, 2017).

External evaluation: This step is performed by the institutional visits of trained KTQ visitors. The KTQ team, generally includes four individuals: a physician, nurse, an economy expert and a coordinator. $K T Q$ visitors evaluate the information in the self-assessment report and the field (KTQ, 2017).

Quality report and provision of certification: A certificate is provided if the institution has a score more than 55 percent in each category from the external evaluation. This certificate is valid for three years. As different from ISO certification procedures, no other external evaluation is made during this time period (KTQ, 2017).

AQUA Institute (Institute for Applied Quality Improvement and Research in Health Care) is an independent and objective institution that was commissioned to provide quality assurance in health countrywide by the Federal Joint Committee, which has been one of the highest decision-making bodies in the German health care system since 2009. It executes evaluation of new treatment models, 
development of quality indicators and their implementation, patient surveys and data-oriented quality management procedures (AQUA, 2013).

The "German Hospital Quality Report" has been issued by AQUA Institute once every three years since 2009. In 2013, 1,557 hospitals transmitted 3.153.099 quality assurance (QA) records. 434 quality indicators were followed up from 30 clinical areas; and fifth was issued in 2015. A positive trend was observed in 403 quality indicators, a rising trend was observed in 40 indicators (9.9\%) and a worsening trend was seen in 17 indicators (4.2\%). Data regarding indicators in 30 below-mentioned clinical areas were collected, analyzed and reported (German Hospital Quality Report 2013) (AQUA, 2013).

The AQUA Institute defined the clinical fields suitable for quality indicators as such: Cholecystectomy, carotid artery revascularization, community-acquired pneumonia, pacemaker (implantation, replacement of generator/battery, revision/system replacement/removal), implantable cardioverter defibrillators (implantation, replacement of generator/battery, revision/system replacement/removal), coronary angiography and percutaneous coronary intervention - PCl, coronary surgery (isolated), aortic valve surgery (isolated), combined coronary and aortic valve surgery, heart transplantation, lung and heart-lung transplantation, liver transplantation, living liver donation, kidney transplantation, living kidney donation, pancreas and pancreas-kidney transplantation, breast surgery, obstetrics, neonatology, gynecological surgery, femoral fractures near the hip joint, hip replacement (primary implantation, revision and component Exchange), total knee replacement (primary implantation), knee replacement (revision, and component Exchange), nursing: prevention of pressure ulcers (German Hospital Quality Report 2013) (AQUA, 2013).

In addition, the Institute for Quality and Efficiency in Health care (IQWiG) is responsible for the evaluation of quality and efficiency of medical treatments, medications, non-pharmacological interventions (e.g., surgical procedures), diagnostic and screening methods and treatment and disease management in Germany. The Institute for Quality and Efficiency in Health care provides information to the public and patients about health in a plain language. The organization is independent from the pharmaceutical industry; its contractor is the Federal Joint Committee and Federal Ministry of Health. Its main task is the evaluation of advantages and disadvantages of medical services and their cost efficiency. The Institute for Quality and Efficiency in Health care prepares reports for medical instruments, surgical techniques, diagnostics and screening methods and besides, treatment guidelines for the doctors (Wolter, 2017).

Introduction of quality studies to the health care institutions in Turkey has started by the provision of TS-EN ISO 9001 certification by private hospitals in the 1990s. Social Insurance Institution (SSK) hospitals have received ISO 9000 quality certification at the end of the studies which were started by 


\section{Yilmaz et al.}

the Ministry of Labour and Social Security in January 2000 for total quality management in health care institutions of Social Insurance Institution (Küçükali and Ta şdemir, 2016). Many private hospitals and some public hospitals have tried to be accredited by accepting standards as criteria with the Joint Commission International (JCl) International Hospital Standards process in 2004 (Kibar, 2014).

Total quality management studies have begun in the hospitals in Turkey that are affiliated with Ministry of Health in October 30, 2001 with "Quality Management Service Directive of Inpatient Treatment Institutions" (Kibar, 2014). In 2005, a hospital evaluation system that is based on the access to health care services, service infrastructure, evaluation of processes, measurement of patient satisfaction and degree of reaching identified goals was adopted for secondary and tertiary care inpatient institutions affiliated to the Ministry of Health. Its task was the "regulation on corporate quality improvement and performance evaluation in inpatient institutions of Ministry of Health". Criteria for quality improvement and evaluation (includes 100 questions) were revised simultaneously and were called "Service Quality Standards". Then, it became a set composed of 621 criteria addressing public, private and university hospitals in 2011. While evaluations of hospitals based on the standards were performed by evaluator teams, which were constituted by Health Directorates in 2005, they were evaluated by evaluators from different cities in the scope of cross evaluation in 2007. Hospital evaluations have been carried out by Ministry of Health in a specific calendar within the scope of Central Evaluation Process since 2010 (Kibar, 2014).

The General Directorate of Health Services (Health Quality and Accreditation Department of the Turkish Ministry of Health) has begun negotiations with The International Society for Quality in Health Care (ISQua) in 2012 in order to generate a national accreditation system. It was agreed to generate a national health accreditation system that was compliant with the quality requirements by examining "ISQua international principles for health care standards" (Küçükali and Ta şdemir, 2016). ISQua international accreditation program was started with the protocol signed in March 20, 2013. ISQua accredited standards of accreditation in health hospital kit (SAS) in January 2014. SAS Evaluator Education Program was prepared to provide the compliance of SAS evaluations by the evaluators in October 2014 and SAS oral and dental health centers (ODHC) set in December 2014 (Küçükali and Ta şdemir, 2016). ISQua accreditation council accredited SAS dialysis set in March 10, 2015 and SAS laboratory set in November 25, 2015 (The Ministry of Health, 2015). With the preparation of $2^{\text {nd }}$ process report, which was demanded to fulfil ISQua criteria, revision of SAS hospital set was approved by ISQua, and "SAS Hospital Set - v1.1" and "SAS Hospital Kit- v1.1" were published including the changes (TUSEB, 2017).

Besides the establishment of National Accreditation System, the Turkish Presidency of Health Institutes (TUSEB) was established with the law accepted in November 19, 2014. Accreditation studies 
International Journal of Management, Economics and Social Sciences

were conducted by the Turkish Institute for Quality and Accreditation in Health care Services (TUSKA) that was established within TUSEB. Within the scope of legislation studies in the institute, "regulation on structuring Turkish health services quality and accreditation institute and execution of its activities" was published in official gazette no. 29935 in December 31, 2016 (TUSEB, 2017).

\section{-Patient and Staff Satisfaction}

Satisfaction surveys are conducted in many German hospitals in order to determine patient and staff satisfaction. These satisfaction survey practices show variations depending on the hospital. For instance, the Landschaftsverband Rheinland (LVR), which is a regional German operator of psychiatric hospitals, carries out triennial surveys for a 12-week period. It is implemented to all patients that are willing to participate. Survey questions are prepared by a team, which was formed in coordination with quality director of the hospital, and same surveys are carried out within the same period in order to group hospitals. All patients and in case of minors also their parents are included in the surveys. The rate of participation in the LVR-Klinik Viersen is around 78 percent.

In Germany, staff satisfaction surveys in the hospitals of the Landschaftsverband Rheinland (LVR) are conducted once every three years as including a 12-week period; and they are implemented to all personnel. Participation is voluntary. The rate of staff participation is around 55 percent. Survey data are collected from the patients and the staff; their results are analyzed and they are shared with each department. Improvement activities are performed in each unit of the hospital.

Satisfaction surveys are also used in Turkey in order to measure patient and staff satisfaction as similar to Germany. "Regulation on Improvement and Evaluation of Quality in Health" that was issued by Health Quality and Accreditation Department and regulated the principles for providing patient and staff satisfaction has gone into effect following its announcement in the Turkish Law Gazette no. 29399 in 06.27.2015. In the scope of this regulation, satisfaction surveys are performed to in-, outand emergency patients each month in the framework of Satisfaction Survey Application Guide (Version-2.0; Revision-00). Only outpatient survey is applied in psychiatric hospitals. Survey results are due to be recorded in Ministry of Health Corporate Quality System (www.kks.saglik.gov.tr) until $15^{\text {th }}$ day of following month. With the analysis of survey data, improvement studies are planned and implemented for the identified areas (The Ministry of Health, 2015).

Staff satisfaction surveys have first started to be conducted in Turkey in the hospitals affiliated with Ministry of Health and Oral and Dental Health Centers in 2008. Surveys are performed twice a year including March and September; and completed by the entry of data into Corporate Quality System (www.kks.saglik.gov.tr) until $15^{\text {th }}$ day of the following month. The questions in staff satisfaction survey should at least include survey questions issued by Ministry of Health. The survey should be performed 
Yılmaz et al.

to at least 50 percent of doctors, health care professionals and other personnel groups (general administration services, technical staff, and service procurement staff). Survey results are evaluated by the management; areas to improve are detected and corrective and preventive actions are planned (The Ministry of Health, 2015).

\section{-Indicator Management}

In Germany, quality indicators that are generally determined by the management in the hospitals are followed at specific time intervals and data are recorded. In addition, the Federal Joint Committee (GBA) identifies indicators for quality assurance (Gemeinsamer Bundesausschuss, 2017). Every hospital in Germany has to monitor these indicators being a part of the annual quality report and published. The indicators that were taken as examples from a psychiatric hospital of Viersen, Germany are categorized in three groups including structural, process and result. They were developed upon the initiative of Professor Wolfgang Gaebel, MD who is the president of European Psychiatry Association (EPA) and listed below (Jänner et al., 2015):

Structural indicators (number of employees/number of patients)

$\checkmark$ The ratio of psychiatrists

$\checkmark$ The ratio of the psychologists who have an additional training for psychotherapy

$\checkmark$ The ratio of the nurses who have taken an education in the field of psychiatric nursing

$\checkmark$ The ratio of nurses.

\section{Process indicators}

$\checkmark$ The number of patients who get a date for further therapy within a week following discharge

$\checkmark$ The ratio of patients who are examined by a doctor at least within 24 hours.

$\checkmark$ The number of assessments of the side effects of medications during the first week of hospitalization

$\checkmark$ The number of psychosocial interventions within a week

$\checkmark$ The number of patients with diagnosis schizophrenia ( $F$ 2) who need at least 4 different antipsychotic medications when they return to their home

$\checkmark$ The number of patients who need at least 4 different antipsychotic medications when they return to their home

$\checkmark$ The ratios of fixations, isolations, forced medications

$\checkmark$ The ratio of re-hospitalizations

Result indicators 
$\checkmark$ Improvement in clinical global impression (CGI) scale in the patients

$\checkmark$ The ratio of suicidal mortality

$\checkmark$ The ratio of death due to other reasons

$\checkmark$ Improvement on the GAF-Scale (global assessment of functioning) at least 10 steps

$\checkmark$ The ratio of patient satisfaction

In Turkey, indicator management in the health care institutions is carried out within the framework of the Indicator Management Guide (Version 1.0, Revision-00) within "regulation on quality improvement and evaluation in health". Indicators are classified under two headings including department-based indicators and clinical indicators (Table 1). A total of 150 indicators are present including 68 department-based indicators (62 compulsory, 6 optional) and 82 clinical indicators (54 compulsory and 28 optional). Clinical indicators are the indicators for coronary artery disease, hip fracture, arthroplasty (knee and hip joint), diabetes mellitus, stroke and cataract operation. Each indicator has a card and data are collected at specified periods. Improvement studies are planned for the required indicators after the analysis of data (The Ministry of Health, 2015).

\begin{tabular}{|c|c|}
\hline Department-Based Indicators & Clinical Indicators \\
\hline Employee Turnover Rate & $\begin{array}{l}\text { The Ratio of Patient who underwent coronary } \\
\text { Angiography }\end{array}$ \\
\hline $\begin{array}{l}\text { Average Reach Time of the Consultant Physician to } \\
\text { the Emergency Service }\end{array}$ & The Ratio of Patients with $\mathrm{HbA}_{1 \mathrm{c}}$ of 7 and below \\
\hline The Ratio of Tomography by Contrast Material & The Ratio of Intravenous Thrombolytic Use in Strokes \\
\hline The Ratio of Pressure Ulcer in Intensive Care Unit & $\begin{array}{l}\text { The Ratio of Patients who underwent Front Vitrectomy } \\
\text { during Operation }\end{array}$ \\
\hline The Ratio of Use of Safe Surgery Checklist & The Ratio of By-Pass Surgery \\
\hline $\begin{array}{l}\text { The Ratio of Caesarean Section (in Maternity } \\
\text { Hospitals) }\end{array}$ & The Ratio of Hip Fracture Mortality \\
\hline Average Reach Time to the Scene at Blue Code & $\begin{array}{l}\text { The Ratio of Patients who underwent Non-invasive Test } \\
\text { before Coronary Angiography }\end{array}$ \\
\hline Employee Satisfaction Rate & $\begin{array}{l}\text { The Ratio of Hospitalized Patients due to Diabetes } \\
\text { (Acute Complications) }\end{array}$ \\
\hline $\begin{array}{l}\text { The Ratio of Rejected Samples in Clinical } \\
\text { Laboratory Tests }\end{array}$ & $\begin{array}{l}\text { The Ratio of Reach to Hospital by Ambulance at } \\
\text { strokes }\end{array}$ \\
\hline Frequency of Medication Errors & $\begin{array}{l}\text { Glaucoma Development Rate within one month } \\
\text { following Cataract Operation }\end{array}$ \\
\hline $\begin{array}{l}\text { Inactivation Time of Hospital Information } \\
\text { Management System }\end{array}$ & $\begin{array}{l}\text { The Ratio of Patients who come for Follow-up within } \\
15 \text { days following Cataract Operation }\end{array}$ \\
\hline
\end{tabular}

Source: OECD/EU (2016)

Table 1. Sample Indicators 


\section{Yılmaz et al.}

\section{CONCLUSION}

Germany and Turkey are two countries showing resemblances with regard to a form of a compulsory, general health insurance system. Although considerable differences in the delivery of health care service remain, the share of health care financing and services provided by the government is great in both countries. Germany has a top-ranking health care system concerning health care indicators compared to other OECD countries. Health expenditures are on the rise in Germany due to an aging population, increasing costs of health care services and new technologies. However, there are some striking differences between the health care system in Germany and Turkey in terms of inpatient outpatient sectorisation. Hospitals in Germany are focused on inpatient care that is strictly separated from outpatient services. In Turkey, treatment services are predominant in the presentation of health care services. One of the major concerns of the compulsory health care system in Germany is increasing health care costs due to over aging and a potential field for private health insurance funds. Major improvements have been made in the German health care system on palliative care whereas this service was begun in Turkey as late as 2015. Although striking differences in practices remain, considering quality studies that have an increasing importance within the hospitals in recent years, practices in Turkey and Germany were found to be similar. In Germany, the quality certification process in health care institutions is voluntary and mostly conducted by an organization called KTQ established in 1997. In Turkey, certification processes were started with the ISO 9001 in the 2000s and are going on with ISQua International Accreditation Program studies. Patient (hospitalized, inpatient and outpatient) satisfaction surveys are performed each month and staff satisfaction surveys are conducted twice a year in Turkey, whereas patient and staff satisfaction surveys are carried out at different periods (for instance, including once in three years) in Germany. Quality indicators where established top down in Turkey by Ministry of Health in Turkey, while they were developed bottom up by self-governing bodies in Germany and quality data of 30 clinical areas is deduced form Hospital Quality Reports published once a year by the German AQUA Institute. In Turkey, departmental and clinical indicators are recorded within the framework of Health Quality Standards.

This study could offer clues and references for future comparative studies on quality indicators. Its main limitation is its focus on psychiatric hospitals. Future studies may also include other main branches of public health care and differences between the inpatient and outpatient sector. Besides, the studies were performed in Germany since the implementation of quality management may offer further guidance for researchers in the fields of aging and rehabilitation.

\section{REFERENCES}


International Journal of Management, Economics and Social Sciences

AQUA - Institute for Applied Quality Improvement and Research in Health Care. (2017) Göttingen: c2017. Institute for Applied Quality Improvement and Research in Health Care GmbH Available from: https://www. aqua-institut.de/en/home/index.htmI

AQUA - Institute for Applied Quality Improvement and Research in Health Care GmbH. (2013). Göttingen: German Hospital Quality Report 2013 Available from: https://sqg.de/upload/CONTENT/EN/Quality-Report/AQUA-German-Hospital-QualityReport-2013.pdf

Ataç Ö \& Sur H. (2016). Sa ğlık sistemleri - 1: Almanya ve Birle şik Krall ık. SD (Sağlı k Dü şüncesi ve T ıp Kültürü) Dergisi, September-October-November 2016;40:60-65 URL: http://www.sdplatform.com/Yazilar/Kose-Yazilari/500/Sagliksistemleri---1-Almanya-ve-Birlesik-Krallik.aspx March 19, 2017.

Bag, B. (2012). Almanya örneğ inde sağl ı k sisteminde palyatif bak Im uygulamalar I. Turkish Journal Of Oncology / Türk Onkoloji Dergisi [serial on the Internet]. (2012, July), 27(3): 142-149. Available from: Academic Search Complete. doi 10.5505/tjoncol.2012.687

Busse, R. \& Blümel, M. (2014). Germany Health system review. Health Systems in Transition, 2014, 16(2):1-296. Available from: http://www.euro.who.int/_data/assets/pdf_file/0008/255932/HiT-Germany.pdf?ua=1

Çiftçi, H. I. (2011) Sa ğl ।k Sistemi ve Finansman ı: Türkiye ve Çe şitli Ülkeler. (Unpublished Master Thesis) Istanbul: Marmara University / Institute of Social Sciences; 2011

Domittner, B., Kernstock, E., \& Nowak, P. (2013). Quality Management Presentation. 2013; URL:http://Ivea.Iv/wpcontent/uploads/2013/07/pielikums_3_Papildus-materi\%C4\%81li.pdf January 16, 2017.

Erol, H., \& Özdemir, A. (2014). Türkiye'de Sa ğl ık Reformları ve Sağl ık Harcamalar ın ı n De ğerlendirilmesi. Journal Of Social Security / SGD-Sosyal Güvenlik Dergisi [serial n the Internet]. (2014, Jan), [cited March 20, 2017]; 4(1): 9-34. Available from: Sociology Source Ultimate.

European Commission. (2017) Germany: Employment, Social Affairs \& Inclusion Your social security rights in Germany Your social security rights. Available from: http://ec.europa.eu/employment_social/empl_portal /SSRinEU /Your\%20social \%20 security\%20rights\%20in\%20Germany_en.pdf European Union.

Gemeinsamer Bundesausschuss. (2017) Berlin: The Federal Joint Committee - G-BA; The Federal Joint Committee. Available from: http://www.english.g-ba.de/

GKV-Spitzenverband. (2017). The National Association of Statutory Health Insurance Funds; Statutory health insurance. Available from: www.gkv-spitzenverband.de

Günayd ın, T. (2016). Almanya'da Sa ğl ık Sistemi Nas ıl Uygulanmaktad ır. URL: http://www.memurmaasmutemeti.com /haber/2006/almanya-saglik-sistemi-nasil-uygulanmaktadir January 15, 2017.

Gutenbrunner, C., Helmert, J., Kimil, A., Markin, K., Salman, R., Reißmann, LM., \& Schwar B. (2015). Alman Emeklilik Sigortas । Kurumu'nun t ।bbi rehabilitasyon hizmeti: Kronik hastal ıklar için yardım. 2015; [1 Sreen] URL: http://docplayer.biz.tr/1161401-Alman-emeklilik-sigortasi-kurumu-nun-tibbi-rehabilitasyon-hizmeti-kronik-hastaliklar-icinyardim.html January 24, 2017.

Halank, A. (2010). Quality management at European Hospitals: staff perceptions of content, implementation and effects in elderly-related, acute stroke care in England and Germany. Ann Arbor: University of Portsmouth (United Kingdom).

Hoffmann, A. \& Schulze E. (2014) Die beste Versicherung für jeden Typ. 2014; [1 Screen]. URL: http://www.stern.de/wirtschaft/versicherung/ratgeber-krankenkasse/die-richtige-krankenkasse-finden-die-besteversicherung-fuer-jeden-typ-3927748.html March 20, 2017

i stanbulluoğlu, H., Güleç, M. \& Oğur, R. (2010) Sa ğl ı k Hizmetlerinin Finansman Yöntemleri. Dirim T ıp Gazetesi, 85(2), 86-99.

Jänner, M., Janssen, B., Großimlinghaus, I., Gaebel, W., Zielasek, J., Wobrock, T., et al. (2015). Assessment of quality indicators with routine data: Presentation of a feasibility test in ten specialist clinics for psychiatry and psychotherapy. Nervenarzt, 86(11): 1393-1399.

Just Landed. (2017). Blog Available from: https://www.justlanded.com/english/Germany/Germany-Guide/Jobs/Unemploymentinsurance

Karar, Ş. (2013). Türkiye'de Sağ I । k Sistemi ve 2003 Sonras । Sa ğl ı kta Dönü şüm Programı (Unpublished Master Thesis). Beykent University / Institute of Social Sciences, Istanbul.

Kibar, E. (2014). Kalite ve Sağ I । k Hizmetlerinde Kalite Standartlar । Uygulamalar I Kocaeli Seka Devlet Hastanesi Örne ği (Unpublished Master Thesis). Istanbul: Institute of Social Sciences University of Beykent (Turkey); 2014

KTQ - The Cooperation for Transparency and Quality in Health care. (2017). KTQ Services; [cited 2017 March 19]. Available from: http://www.ktq-international.com

Küçükali, H., \& Taşdemir, M. (2016). Sağlıkta kalitenin eksik basamağ I. 2016;URL: http://www.sdplatform.com/Dergi/921/Saglikta-kalitenin-eksik-basamagi.aspx January 16, 2017

Mossialos, E., Wenzl, M., Osborn, R. \& Sarnak D. (2016) International Profiles of Health Care System 2015; URL:http://www.commonwealthfund.org/ /media/files/publications/fundreport/2016/jan/1857_mossialos_intl_profiles_2015_v7.pdf January 24, 2017.

OECD. (2016). Health expenditure in relation to GDP, in Health at a Glance: Europe 2016: State of Health in the EU Cycle, OECD Publishing,

Paris.

Available from: http://www.oecd-ilibrary.org/social-issues-migration-health/health-at-a-glance-europe-2016/healthexpenditure-in-relation-t o-gdp_health_glance_eur-2016-34-en January 15, 2017

OECD/EU. (2016). Health at a Glance: Europe 2016 - State of Health in the EU Cycle, OECD Publishing, Paris. Available From: http://www.oecd-ilibrary.org/social-issues-migration-health/health-at-a-glance-europe-2016_9789264265592-en

Renger, F, A. Czirfusz. (2016). Structural Comparison Of Management Apsects Of Community Health care Centres In Europe With Special Focus On Germany. Academy of Strategic Management Journal, 15 (1):41-48. 
Sa ğl ।k Bakanl ı ğ । Sa ğlıkta Kalite ve Akreditasyon Daire Ba şkanl । ğ l. (2015). Ankara: c2015 "Türkiye Sa ğlıkta Akreditasyon Sistemi"'ne Yönelik Çal ı şmalar ın Resmen Ba şıad ı ğ ı na Dair Duyuru; [about 5 screens]. Available from: http://www.kalite.saglik.gov.tr/TR,8834/genel-duyurular.html

Sa ğ । k Bakanl ı ğ I Sa ğl ı kta Kalite ve Akreditasyon Daire Ba şkanl । ğ । . (2015). Ankara: c2015 [cited 2017 January 17] Sa ğl । k Bakanl ı ğ I Sa ğ I kta Kalite ve Akreditasyon Daire Ba şkanl । ğ I Memnuniyet Anketleri Uygulama Rehberi-2016 Available from: http://www.kalite.saglik.gov.tr/Eklenti/3534,21072015memnuniyetanketleriuygulamarehberipdf.pdf?0

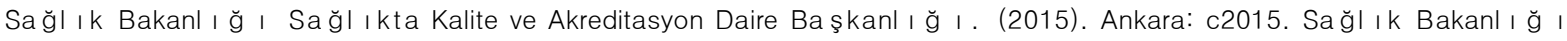
Sağlıkta Kalite ve Akreditasyon Daire Başkanlığ I Gösterge Yönetimi Rehberi Available from: http://www.kalite.saglik.gov.tr/Eklenti/3502, gostergeyonetimirehberi-1408151 pdf.pdf?0

Tatar, P. (2014). Sa ğ I lk Hizmetlerinin Finansman Modelleri: Sosyal Sa ğı ık Sigortas ın ın Türkiye'de Geli şimi: T. C. Sosyal Güvenlik Kurumu; 2014. Available from: DergiPark.

The Ministry of Health. (2015). Ankara: I statistik Y । ll । klar ।; c2016 [cited 2017 March 19]. Sa ğ I k I statistikleri Y । ll । ğ । 2015 Available from: http://www.saglikistatistikleri.gov.tr/dosyalar/SIY_2015.pdf

The Institute for Quality and Efficiency in Health care (IQWiG). (2017). Köln: The Institute; [cited 2017 January 17]. Responsibilities and objectives of IQWiG; Available from: https://www.iqwig.de/en/about-us/responsibilities-and-objectivesof-iqwig.2946.html

Tradingeconomics.com. (2017). Germany GDP per capita. Available from: http://www.tradingeconomics.com/germany/gdpper-capita

Tradingeconomics.com. (2017). Turkey GDP per capita Available from: http://www.tradingeconomics.com/turkey/gdp

Türkiye Sa ğl ı k Enstitüleri Ba ş kanl ı ğ I - TUSEB. (2017). Ankara: The Institute; [cited 2017 January 17]. Türkiye'de Ulusal Akreditasyon Süreci Ba ş। ı yor; Available from: http://www.tuseb.gov.tr/haber_detay.php?id=38

Wild, C. \& Gibis, B. (2003) Evaluations of health interventions in social insurance-based countries: Germany, the Netherlands, and Austria. Health Policy (2003, Feb 1), 63(2): 187-196. Available from: Scopus®.

Wolter, B. P. (2017). About us An introduction to IQWiG (The Institute for Quality and Efficiency in Health care). URL: https://www.iqwig.de/download/IQWIG_about_us_2016.pdf January 17, 2017

Worldometers.info. (2017). Germany Population. Available from: http://www.worldometers.info/world-population/germanypopulation/

Worldometers.info. (2017). Turkey Population. Available from: http://www.worldometers.info/world-population/turkeypopulation.

Yaman K. (2014). Alman özel sa ğ I lk sigorta şirketlerinin finansman prensipleri. Yönetim Ve Ekonomi Ara şt ı rmalar Dergisi (2014, Jan 1), (24): 281. Available from: ULAKB i M Ulusal Veri Tabanlar I (UVT) - ULAKBIM Turkish National Databases.

Yurdado ğ, D. (2013) Türkiye'de Sa ğı ık Harcamalar ın ın Finansman ı ve Analizi [monograph on the Internet]. [place unknown]: Çukurova Üniversitesi; 2013. [cited March 19, 2017]. Available from: DergiPark. 